\title{
Molecular detection and characterisation of begomovirus causing bean yellowing disease in Sri Lanka
}

\author{
K.D.R.C. Rienzie ${ }^{1}$, W.A.R.T. Wickramaarachchi ${ }^{2}$, D.M. De Costa $^{1}$ and W.M.G.U. Wijesooriya ${ }^{1}$ \\ ${ }^{1}$ Department of Agricultural Biology, Faculty of Agriculture, University of Peradeniya, Peradeniya. \\ ${ }^{2}$ Division of Plant Pathology, Horticultural Crop Research and Development Institute, Gannoruwa, Peradeniya.
}

Revised: 24 July 2015; Accepted: 01 December 2015

\begin{abstract}
Bean (Phaseolus vulgaris L.) is one of the major vegetable crops cultivated in tropical, sub-tropical and temperate regions in the world. Bean yellowing disease (BYD), which was first reported in 1999 from Sri Lanka is still a serious viral threat to bean cultivation causing severe yield reduction. In this study, polymerase chain reaction (PCR) assays using degenerate (universal) primers were conducted with the aim of developing molecular techniques to detect the virus. Two degenerate primer pairs, namely, Deng 540/541 and AV494/AC1048 used in the PCR reactions confirmed the association of a begomovirus with the BYD by giving the desired core coat protein amplicons of $520 \mathrm{bp}$ and $550 \mathrm{bp}$, respectively. The resulting amplicons were subjected to DNA sequencing and the sequence data were analysed to determine the phylogenetic and molecular evolutionary relationships with other related begomovirus sequences obtained from the GenBank. The analysis revealed that the virus associated with BYD (BYVD-GN-SL-Partial) is closely related to Horsegram [Macrotyloma uniflorum (Lam.) Verdc.] yellow mosaic virus isolate (HgYMV-LK: 09-Bean) reported in Sri Lanka. Further, the DNA sequence of BYVD-GN-SL-Partial was distinctively clustered with the Indian HgYMV sequences and positioned in between the Mungbean yellow mosaic virus (MYMV) sequences.
\end{abstract}

Keywords: Begomoviruses, Horsegram yellow mosaic virus (HgYMV), molecular characterisation, polymerase chain reaction $(\mathrm{PCR})$.

\section{INTRODUCTION}

Bean (Phaseolus vulgaris L.) is one of the major vegetable crops cultivated in Sri Lanka up to an extent of 8000 ha and has an annual production of 40,000 mt. This accounts for $23 \%$ of the total extent of up country vegetables
(Anon, 2010). Among the biotic constraints of bean production, viral diseases have been identified as a major threat in Sri Lanka due to the spread of bean yellowing disease (BYD) in epidemic proportions. BYD is caused by the Horsegram yellow mosaic virus (HgYMV), which is a bipartite begomovirus first reported in 1999 (Monger et al., 2010) and continues to be the major threat for bean cultivation in Sri Lanka. Hence, accurate detection and characterisation of the virus is a crucial prerequisite when formulating management strategies. Early diagnosis of viral diseases along with accurate identification of their causal agents is immensely important in managing such outbreaks (Ozalan et al., 2006). Using symptomatology alone to detect viral diseases is not always accurate due to similar symptoms being caused by other pathogens. Polymerase chain reaction (PCR) technique using degenerate primers is a rapid, efficient, and a reliable method widely adopted in virus detection. Therefore in this study, two degenerate (universal) primer pairs, namely, Deng 540/541 and AV494/AC1048 were used to detect begomovirus associated with beans in Sri Lanka. Certain weeds act as alternate hosts of begomovirus, hence management of the viral diseases becomes more challenging. The present study also focused on using molecular methods to identify local weed species capable of harbouring BYD causing viruses. Begomoviruses have been categorised as major quarantine pests in the world (Hamilton, 2000). Comparing viral genome sequence information is vital in predicting possible evolutionary pathways and transboundary movements, which is ultimately important in executing appropriate quarantine measures. This is the first detailed study to reveal important molecular level information useful for effective management of the BYD in Sri Lanka. 


\section{METHODOLOGY}

\section{Bean leaf samples for PCR}

Tender bean leaf samples of various cultivars showing typical BYD symptoms were collected from farmer fields of different administrative districts of Sri Lanka, namely, Kandy (e.g. Kadugannawa and Yatinuwara), Matale (e.g. Naula), Nuwara Eliya (e.g. Seetaeliya) and Badulla (e.g. Bandarawela). Apparently healthy leaf samples of the same variety were also collected from the same locations as control samples. All the leaf samples were collected when the plants were at the early flowering stage and from the plants grown during the same growing season.

\section{Weed plants for transmission studies}

Seeds of Hedyotis corymbosa (Rubiaceae) and Ageratum spp. (Compositae) were sown in pots containing sterilised soil maintained in insect-proof cages. The seeds of Ageratum spp. were obtained from stock cultures maintained at the Division of Plant Pathology, Horticultural Crop Research and Development Institute (HORDI), Gannoruwa, Peradeniya and the seeds of Hedyotis corymbosa were collected from plants grown in experimental fields of HORDI, which did not show symptoms of viral infection.

\section{Transmission of the virus into weed plants using whiteflies}

Two-week old seedlings of the weed species were inoculated using viruliferous whiteflies that had been allowed to feed for a period of $24 \mathrm{hrs}$ on bean plants showing characteristic symptoms and confirmed as infected with HgYMV. Using an aspirator randomlypicked whiteflies from the bean plants were transferred to individual weed plants grown in separate micro transmission cages at a rate of 10 whiteflies/weed plant.
Three such weed plants per each weed species were inoculated with the whiteflies. After an inoculation access period of $24 \mathrm{hrs}$ on the weed plants, the plants were sprayed with $200 \mathrm{~g} / \mathrm{L} \mathrm{SL}(1 \mathrm{~mL} / \mathrm{L})$ imidachloprid (Admire $^{\circledR}$, Bayer Crop Sci.) to eliminate the whiteflies. The weed plants were then maintained in the insectproof cages for two weeks until symptom development. Tender leaf samples showing symptoms of viral infection were collected from the weed plants and subjected to extraction of DNA. Two other sets of the same weed species inoculated with non-viruliferous whiteflies were maintained as controls under the same conditions.

\section{Selection of degenerate primers}

Begomovirus specific degenerate primers (Promega, WI, USA), namely, Deng 540/541 (Deng et al., 1994) and AV 494/AC 1048 (Wyatt \& Brown, 1996) were used in this study (Table 1). These primers amplify a part of coat protein gene in DNA-A component of the begomoviruses.

\section{DNA extraction from leaf tissues}

Total DNA was extracted from the leaves according to the CTAB (Cetyltrimethylammoniumbromide) extraction protocol by Lodhi et al. (1994) with a few modifications. Briefly, $150 \mathrm{mg}$ of tender leaf tissues from each type of plant were homogenised with $1.5 \mathrm{~mL}$ of preheated (at $65^{\circ} \mathrm{C}$ ) DNA extraction buffer $(0.1 \mathrm{M}$ Tris $\mathrm{HCl}, 0.2 \mathrm{M}$ EDTA, 1.4 M NaCl, 2 \% CTAB, 1 \% PVP, $\beta$-mercaptoethanol). The homogenised material was transferred into a $1.5 \mathrm{~mL}$ eppendorf tube and incubated at $65{ }^{\circ} \mathrm{C}$ for $30 \mathrm{~min}$. The tube was next centrifuged at $2,000 \mathrm{rpm}$ for $1 \mathrm{~min}$ and the supernatant was transferred to a new eppendorf tube. An equal volume of chloroform: isoamylalcohol (24:1) was added and mixed by gentle inversion and centrifuged for $10 \mathrm{~min}$ at $12,000 \mathrm{rpm}$. The resulting supernatant was transferred to another eppendorf tube, into which isopropanol was added. The tube was then inverted several times and incubated overnight at $-20{ }^{\circ} \mathrm{C}$. DNA was pelleted by centrifugation

Table 1: Sequences of selected degenerate primers

\begin{tabular}{cccc}
\hline Primer & \multicolumn{1}{c}{ Sequence } & Product & Reference \\
\hline Deng 540 & 5'-TAATATTACC(K)G(W)(K)G(V)CC(S)C-3' & & \\
Deng 541 & 5'-TGGAC(Y)TT(R)CA(W)GG(B)CCTTCACA-3' & $\sim 520$ bp & Deng et al. (1994) \\
AV 494 & 5'-GCC(Y)AT(R)TA(Y)AG(R)AAGCC(M)AG-3' & & \\
AC 1048 & 5'-GG(R)TT(D)GA(R)GCATG(H)GTACATG-3' & $\sim 550$ bp & Wyatt \& Brown (1996) \\
\hline
\end{tabular}

Ambiguity characters according to IUPAC nomenclature are represented as $\mathrm{B}=(\mathrm{C}, \mathrm{G}, \mathrm{T}) ; \mathrm{D}=(\mathrm{A}, \mathrm{G}, \mathrm{T})$; $H=(A, C, T) ; K=(G, T) ; M=(A, C) ; R=(A, G) ; S=(C, G) ; V=(A, C, G) ; W=(A, T) ; Y=(C, T)$ 
for $5 \mathrm{~min}$ at $12,000 \mathrm{rpm}$. The pellet was then washed with $70 \%$ ethanol and dried at room temperature for $20 \mathrm{~min}$. Finally the pellet was dissolved in $100 \mu \mathrm{L}$ of $1 \times \mathrm{TE}$ buffer and stored at $-20{ }^{\circ} \mathrm{C}$.

\section{PCR amplification}

Each PCR reaction was performed in the thermal cycler MultiGene (Labnet International Inc., NJ, USA) using $25 \mu \mathrm{L}$ of reaction mixture. This mixture consisted of $2.0 \mu \mathrm{L}$ of total DNA extracted from infected bean leaf tissues and diluted up to $1 / 25(80-100 \mathrm{ng}), 0.2 \mu \mathrm{L}$ Taq DNA polymerase $(5 \mathrm{U} / \mu \mathrm{L}), 2.5 \mu \mathrm{L}$ of $10 \times$ PCR buffer (100 mM Tris-HCl, pH 8.3, $500 \mathrm{mM} \mathrm{KCl,} 15 \mathrm{mM}$ $\left.\mathrm{MgCl}_{2}\right), 0.5 \mu \mathrm{L}$ of $25 \mathrm{mM} \mathrm{MgCl}, 2.0 \mu \mathrm{L}$ each primer (10 mM), $2.0 \mu \mathrm{L}$ dNTPs mix (2.5 mM each), and sterile water to make up the required volume.

The reaction mixture was subjected to one cycle of initial denaturation at $94{ }^{\circ} \mathrm{C}$ for 5 min followed by 30 cycles of denaturation at $94{ }^{\circ} \mathrm{C}$ for $30 \mathrm{~s}$, annealing at $58{ }^{\circ} \mathrm{C}$ for $30 \mathrm{~s}$, extension at $72{ }^{\circ} \mathrm{C}$ for $45 \mathrm{~s}$ and a final extension at $72{ }^{\circ} \mathrm{C}$ for $10 \mathrm{~min}$ for Deng 540 and Deng 541 primers.

\section{Optimising PCR conditions for AV 494 and AC 1048 primers}

The gradient PCR reactions were performed in the range of $55-65{ }^{\circ} \mathrm{C}$ under two dilutions of genomic DNA template $[1 / 10(200-250 \mathrm{ng})$ and $1 / 25(80-100 \mathrm{ng})]$ to determine the optimum annealing temperature for AV 494 and AC 1048 and optimum dilution of DNA, respectively.

\section{Analysis of PCR products}

The PCR products were analysed on $1.0 \%$ agarose gel at $60 \mathrm{~V}$ for $1 \mathrm{hr}$ in $1 \times$ TBE buffer [100 mM Tris $(\mathrm{pH} 8)$, Boric acid, 0.5 M EDTA (pH 8)]. The gel was stained with ethidium bromide at $0.5 \mu \mathrm{g} / \mathrm{mL}$. PCR product size was estimated using a 100 bp DNA size marker (Promega, WI, USA).

\section{DNA sequencing of partial genome of BYD}

A fragment of the core coat protein gene present on the genome A component of the causal virus of BYD was amplified using the above two primer pairs and sent for DNA sequencing to Genetech Pvt. Ltd., Sri Lanka. The sequence information obtained was subjected to homology search using the basic local alignment tool (BLAST) (Altschul et al., 1990) available at www.ncbi. nlm.nih.gov/BLAST (GenBank).

\section{Phylogenetic and molecular evolutionary analysis}

Thirty accessions showing higher homology with the DNA sequence obtained from the present study (designated as BYVD-GN-SL-Partial) were selected from the DNA databases available at www.ncbi.nlm. nih.gov/BLAST (GenBank). Using MEGA 4.0 software package, phylogenetic and molecular evolutionary relationships of the DNA sequences were determined by neighbour-joining method at 1000 bootstrap value (Tamura et al., 2007).

\section{RESULTS}

Appearance of symptoms on weed plants inoculated with viruliferous whiteflies

Virus-like symptoms appeared on the leaves of $H$. corymbosa after two weeks of inoculation using viruliferous whiteflies. However, the symptoms were different to the typical yellowing symptoms seen on beans and showed crinkling of both adaxial and abaxial surfaces of the leaves (Figure 1). In contrast, Ageratum spp. did not show any virus-like symptom (data not shown).

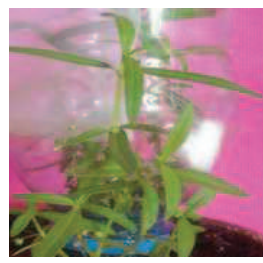

(A)

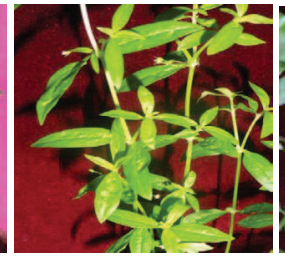

(B)

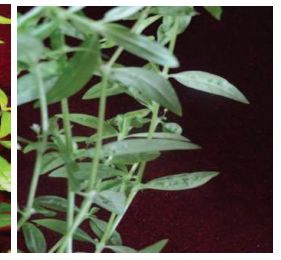

(C)
Figure 1: (A) Healthy H. corymbosa plant; (B) adaxial surface of inoculated $H$. corymbosa leaves and (C) abaxial surface of inoculated $H$. corymbosa leaves after 2 weeks of inoculation with viruliferous whiteflies

\section{PCR by degenerate primers}

Consistent amplification of $\sim 520$ bp fragments was obtained from DNA extracted from all bean leaf samples, which showed characteristic yellowing symptoms, and also in the two virus-inoculated weed species (i.e. Ageratum spp. and H. corymbosa) with Deng 540/541 primer pair (Figure 2). The amplification through gradient PCR using AV 494/AC 1048 primers showed faint bands of $\sim 550 \mathrm{bp}$ at the annealing temperature of $56{ }^{\circ} \mathrm{C}$ for $2 \mathrm{~min}$ (data not shown) and was found to be non-consistent over PCR assays performed within the range of $55-65{ }^{\circ} \mathrm{C}$. No amplification resulted in the DNA extracted from apparently healthy leaves of bean plants and weeds with any of the above primer pairs. 


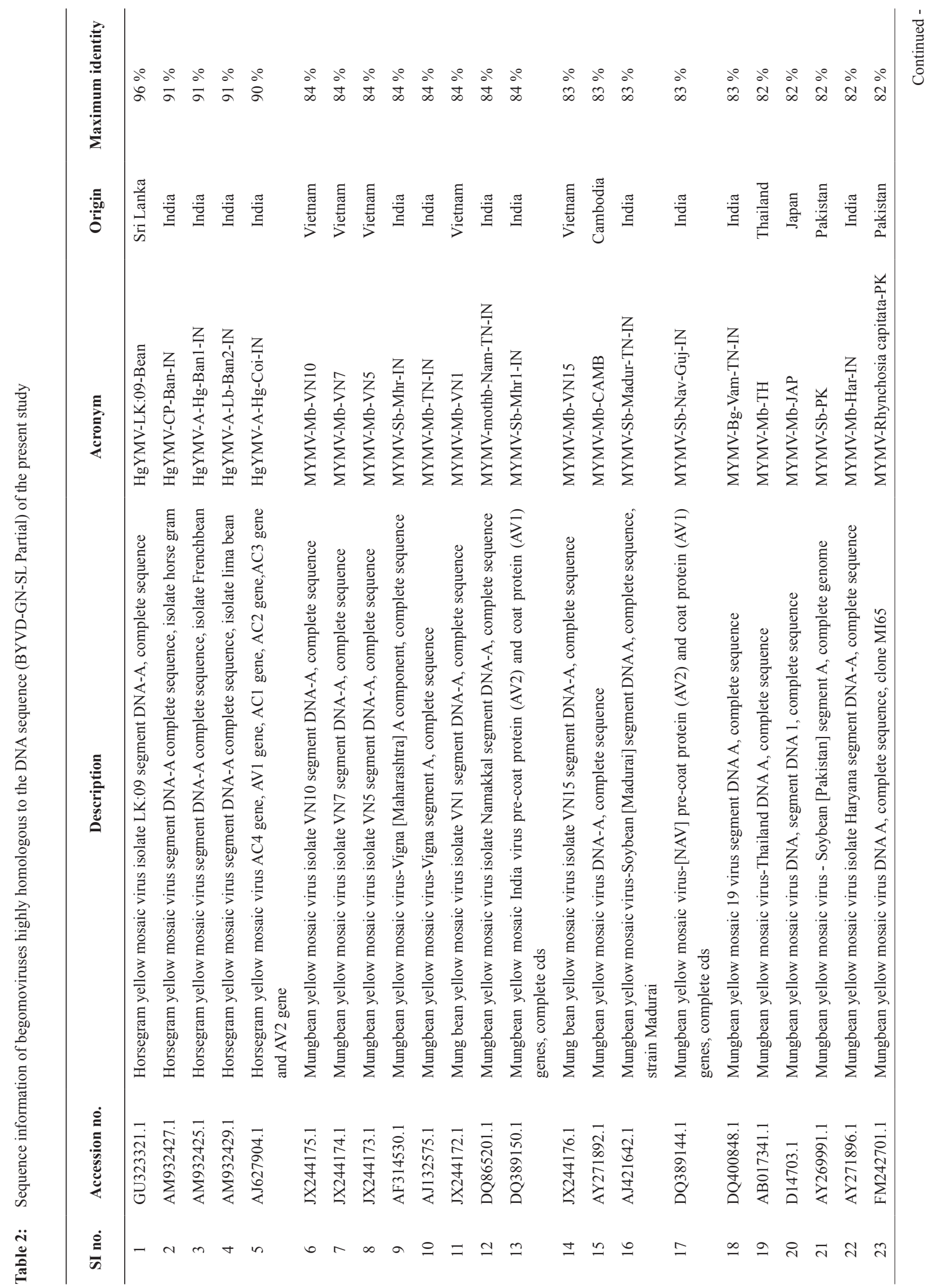




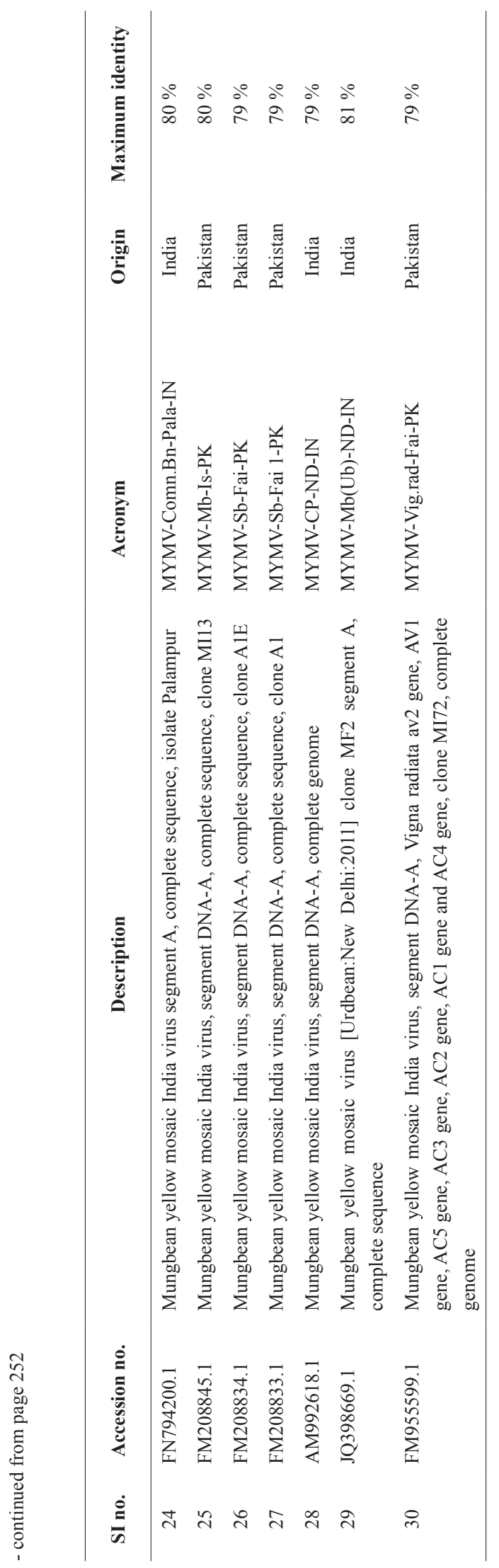

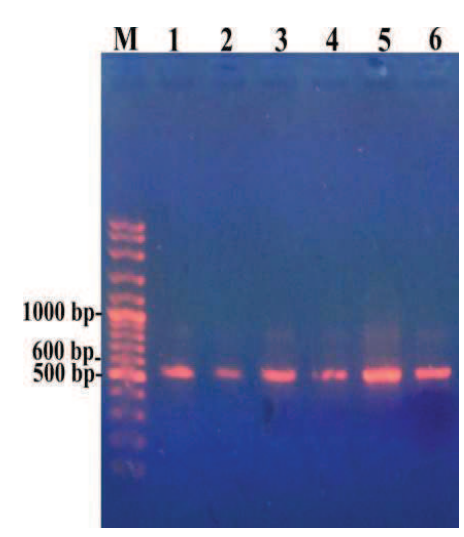

Figure 2: PCR amplification of virus infected beans and virus inoculated weeds using Deng 540/541 primers. (Lane M: 100 bp marker; Lanes 1, 2, 3, and 4: BYD infected beans collected from Kandy, Matale, Nuwara Eliya and Badulla Districts respectively; Lane 5: Ageratum spp.; Lane 6: H. corymbosa)

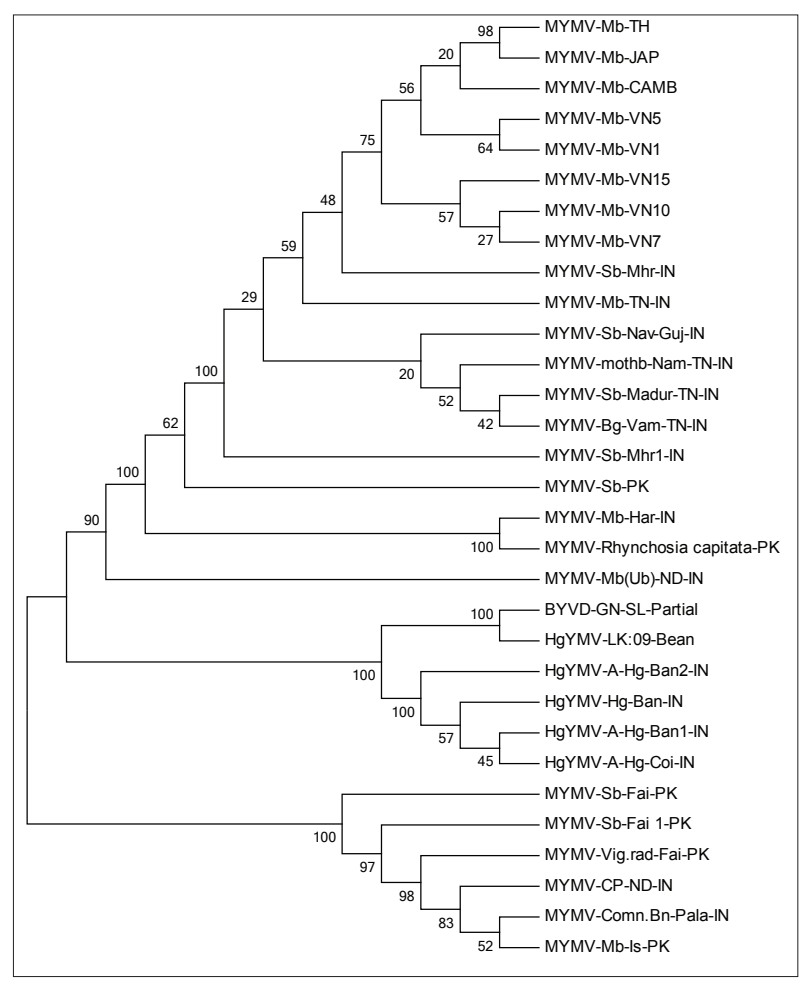

Figure 3: Molecular and evolutionary relationship of partial CP gene of begomoviruses associated with BYD in Sri Lanka (BYVD-GN-SL-Partial) to other homologous sequences 


\section{Phylogenetic and molecular evolutionary analysis}

Closely related sequences to the DNA sequence of BYVD-GN-SL-Partial obtained through DNA homology search are given in Table 2. Phylogenetic and molecular evolutionary relationships obtained after analysing the 30 sequences using MEGA 4.0 software at 1000 bootstrap value are illustrated in Figure 3.

\section{DISCUSSION}

The present study confirmed the causal virus of BYD as a begomovirus, which can be successfully detected in infected plant tissues using Deng 540/541 primers and AV 494/AC 1048 primers. Findings of the present study agree with the existing research information that both Deng 540/541 (Rajeshwari et al., 2005; Govindappa et al., 2011; Bandaranayake et al., 2014) and AV 494/AC 1048 (Raj et al., 2008; Govindappa et al., 2011) primers are efficient tools to detect begomoviruses.

Although Wyatt and Brown (1996) have successfully detected different begomoviruses using AV 494/AC 1048 primers, no consistent amplification was obtained for BYD in the present study. The poor amplification could be due to less affinity of the primers towards template DNA and the presence of PCR inhibitors (Ghosh et al., 2009). The present study revealed the possibility of artificial inoculation of the begomovirus associated with BYD into Ageratum spp. and $H$. corymbosa through whiteflies indicating that they are possible alternative hosts that can harbour the virus naturally. According to Saunders et al. (2002) A. conizoides is a host of Sri Lankan cassava mosaic virus (SLCMV), which is also a begomovirus. Therefore, a detailed study on natural weed flora harbouring this virus is worthwhile.

The amplified DNA fragment of the BYD causal virus (BYVD-GN-SL-Partial) showed $96 \%$ sequence homology to HgYMV-LK:09-Bean isolate, which has been isolated from beans in Sri Lanka by Monger et al. (2010). BYVD-GN-SL-Partial also showed $90-91 \%$ sequence homology to several HgYMV isolates reported from India in Horsegram, Lima bean and French bean (Table 2). The DNA sequence of the present study formed a sub cluster with $\mathrm{HgYMV}$ LK:09-Bean isolated by Monger et al. (2010) from beans in Sri Lanka, indicating the genetic similarity of BYVD-GN-SL-Partial with HgYMV-LK:09-Bean. Furthermore, both sequences (BYVD-GN-SL and HgYMV-LK:09-Bean) formed a distinct cluster with other HgYMV isolates, namely, HgYMV-CP-Ban-IN, HgYMV-A-Hg-Ban1-IN, HgYMV-A-Lb-Ban2-IN and HgYMV-A-Hg-Coi-IN reported in India suggesting the close genetic relationship of the begomovirus associated with bean yellowing disease in Sri Lanka with the HgYMV isolates in India. Thus phylogenetic analysis provides information that the begomovirus associated with BYD can be a pseudorecombinant of begomoviruses associated with the Horsegram yellow mosaic disease caused by HgYMV and mungbean yellow mosaic disease caused by mungbean yellow mosaic virus (MYMV). Similarly, Qazi et al. (2007) have suggested pseudorecombination as a possible reason for clustering of MYMV-(IN:Mad:Sb) along with HgYMV. Further, a higher degree of genetic similarity of the mungbean yellow mosaic virus with HgYMV-(IN:Coi) has been reported by Girish and Usha (2005).

The present study provides important information on rapid and precise detection of the BYD, its genetic characteristics and evolutionary relationships, and potential weed hosts. This information can be utilised to formulate future management strategies useful for effective management of the virus through crop management and quarantine practices.

\section{REFERENCES}

1. Altschul S.F., Gish W., Miller W., Myers E.W. \& Lipman D.J. (1990). Basic local alignment search tools. Journal of Molecular Biology 215: 403 - 410.

2. Anonymous (2010). AgStat: Pocket Book of Agricultural Statistics. Socio Economics and Planning Centre, Department of Agriculture, Gannoruwa, Peradeniya.

3. Bandaranayake W.M.E.K., Wickramaarachchi W.A.R.T., Wickramasinghe H.A.M., Rajapakshe R.G.A.S. \& Dissanayake D.M.K.K. (2014). Molecular detection and characterization of begomoviruses associated with cucurbitaceae vegetables in Sri Lanka. Journal of the National Science Foundation of Sri Lanka 42(3): 265 - 271. DOI: http://dx.doi.org/10.4038/jnsfsr.v42i3.7400

4. Deng A., Mcgrath P.F., Robinson D.J. \& Harrison B.D. (1994). Detection and differentiation of whitefly transmitted geminiviruses in plants and vector insects by the polymerase chain reaction with degenerate primers. Annals of Applied Biology 125(2): 327 - 336.

DOI: http://dx.doi.org/10.1111/j.1744-7348.1994.tb04973.x

5. Ghosh R., Paul S., Ghosh S.K. \& Roy A. (2009). An improved method of DNA isolation suitable for PCR based detection of begomoviruses from jute and other mucilaginous plants. Journal of Virological Methods 159: $34-39$.

DOI: http://dx.doi.org/10.1016/j.jviromet.2009.02.020

6. Girish K.R. \& Usha R. (2005). Molecular characterization of two soybean-infecting begomoviruses from India and evidence for recombination among legume-infecting begomoviruses from South-East Asia. Virus Research 108: $167-176$.

DOI: http://dx.doi.org/10.1016/j.virusres.2004.09.006 
7. Govindappa M.R., Shankergoud I., Shankarappa K.S., Wickramaarachchi W.A.R.T., Reddy B.A. \& Rangaswamy K.T. (2011). Molecular detection and partial characterization of begomovirus associated with leaf curl disease of sunflower (Helianthus annus) in Southern India. Plant Pathology Journal 10(1): 29 - 35. DOI: http://dx.doi.org/10.3923/ppj.2011.29.35

8. Hamilton D. (2000). Solanaceous crop begomoviruses: Additions to EPPO List. European and Mediterranean Plant Protection Organization Report for March 2000. European and Mediterranean Plant Protection Organization, Paris, France.

9. Lodhi M.A., Ye G.N., Weeden N.F. \& Reisch B.I. (1994). A simple and efficient method for DNA extraction from grapevine cultivars and Vitis species. Plant Molecular Biology Reporter 12(1): 6 - 13 .

DOI: http://dx.doi.org/10.1007/BF02668658

10. Monger W.A., Harju V., Nixon T., Bennett S., Reeder R., Kelly P. \& Ariyarathne H.M. (2010). First report of Horsegram yellow mosaic virus infecting Phaseolus vulgaris in Sri Lanka. New Disease Reports 21: 16. Available at www.ndrs.org.uk DOI: http://dx.doi.org/10.5197/j.2044-0588.2010.021.016

11. Ozalan M., Aytekin T., Bas B., Kilic I.H., Afacan I.D. \& Dag D.S. (2006). Virus diseases of cucurbits in GaziantepTurkey. Plant Pathology Journal 5: 24 - 27. DOI: http://dx.doi.org/10.3923/ppj.2006.24.27

12. Qazi J., Ilyas M., Mansoor S. \& Briddon R.W. (2007). Legume yellow mosaic viruses: genetically isolated begomoviruses. Molecular Plant Pathology 8: 343 - 348 . DOI: http://dx.doi.org/10.1111/j.1364-3703.2007.00402.x

13. Raj S.K., Snehi S.K., Khan M.S., Singh R. \& Khan A.A. (2008). Molecular evidence for association of tomato leaf curl New Delhi virus with leaf curl disease of papaya (Carica papaya L.) in India. Australasian Plant Disease Notes 3(1): 152 - 155.

DOI: http://dx.doi.org/10.1071/DN08059

14. Rajeshwari R., Reddy R.V.C., Maruthi M.N., Colvin J., Seal S.E. \& Muniyappa V. (2005). Host range, vector relationships and sequence comparison of a begomovirus infecting Hibiscus in India. Annals of Applied Biology 147(1): $15-25$.

DOI: http://dx.doi.org/10.1111/j.1744-7348.2005.00005.x

15. Saunders K., Nazeera S., Mali V.R., Malathi V.G., Briddon R., Markham P.G. \& Stanley J. (2002). Characterization of Sri Lankan cassava mosaic virus and Indian cassava mosaic virus: evidence for acquisition of a DNA B component by a monopartite begomovirus. Virology 293: 63 - 74 . DOI: http://dx.doi.org/10.1006/viro.2001.1251

16. Tamura K., Dudley J., Nei M. \& Kumar S. (2007). MEGA4: molecular evolutionary genetics analysis (MEGA) software version 4.0. Molecular Biology and Evolution 24(8): 1596 - 1599.

DOI: http://dx.doi.org/10.1093/molbev/msm092

17. Wyatt S.D. \& Brown J.K. (1996). Detection of subgroup III geminivirus isolates in leaf extracts by degenerate primers and polymerase chain reaction. Phytopathology 86(12): $1288-1293$.

DOI: http://dx.doi.org/10.1094/Phyto-86-1288 